\title{
Evolution of a national urine quality assurance programme: the Australasian experience, 1981-1983
}

\author{
MDS SHEPHARD, LA PENBERTHY, CG FRASER* \\ From the Department of Clinical Biochemistry, Flinders Medical Centre, Bedford Park, \\ South Australia 5042, Australia
}

SUMMARY A national interlaboratory quality assurance programme for quantitative urine analysis has been conducted over the past three years in Australasia under the auspices of the Royal College of Pathologists of Australasia and the Australian Association of Clinical Biochemists.

Analysis of urine calcium has consistently improved over the three year period whereas urine protein analysis has consistently declined. Based on the findings in 1983, it is considered that urine sodium, potassium, creatinine, phosphate, glucose, and chloride are currently being measured satisfactorily by Australasian laboratories, while the analyses of urine proteins, urate, oxalate, 5-hydroxyindoleacetic acid and 4-hydroxy-3-methoxymandelic acid still require substantial improvement.

All analyses performed in the clinical biochemistry laboratory should be assessed through interlaboratory quality assurance survey. A plethora of such surveys of regional, national, and international natures exist for those analytes in serum or plasma which are the major source of work for the clinical biochemist. In contrast, there are few reports on the design and execution of quality assurance surveys concerned with the performance of analysis of other body fluids. Although quantitative analysis of urine represents a minor but nevertheless important component of the workload of most laboratories, there are, with the exception of the urine surveys of the College of American Pathologists, ${ }^{1-3}$ few reports on quality assurance programmes for analytes in this biological fluid. In 1980 a small scale regional survey of the performance of quantitative analysis of urinary analytes was therefore carried out in South Australia as a necessary prerequisite to the future establishment of an Australasian urine quality assurance survey. ${ }^{4}$

Under the auspices of the Australian Association of Clinical Biochemists and the Royal College of Pathologists of Australasia, a programme was instituted in 1981 to assess the standard of performance

\footnotetext{
*Present address: Department of Biochemical Medicine, Ninewetls Hospital and Medical School, University of Dundee, Dundee DD1 9SY, Scotland.
}

Accepted for publication 15 December 1983 of the quantitative analysis of 10 urinary constituents throughout Australasia. ${ }^{5}$ The constituents surveyed were sodium, potassium, osmolality, urea, creatinine, calcium, phosphate, urate, proteins, and glucose. The programme was also designed to provide rapid feedback to participants on their comparative performance and included novel features such as the use of target values, allowable limits for total laboratory error, linearly related analyte concentrations for all samples distributed, and computer generation of graphic interim and final reports.

In 1982, the Australasian Urine Programme was similarly conducted, ${ }^{6}$ with the range of analytes surveyed being extended to include chloride, oxalate, 4-hydroxy-3-methoxymandelic acid (HMMA), and 5-hydroxyindoleacetic acid (5HIAA).

In 1983 a further survey was conducted in order to provide continuing review of the standard of performance of urine analyses. ${ }^{7}$ The range of analytes was further extended to include amylase (EC 3.2.2.1).

Through the evolution of the Australasian Urine Programme over the past three years, a number of analytical problems have been highlighted and the standard of performance achieved by laboratories for certain urine chemistries has improved substantially. This paper summarises the programmes implemented and the results obtained over the three years and reviews the progress made towards attempting to raise the standard of performance of 
Table 1 Participants in the Australasian urine programmes: 1981-1983

\begin{tabular}{lccr}
\hline State or country & \multicolumn{3}{l}{ No of laboratories } \\
\cline { 2 - 4 } & 1981 & 1982 & 1983 \\
\hline New South Wales & 32 & 35 & 33 \\
Northern Territory & 1 & 2 & 2 \\
Queensland & 14 & 11 & 13 \\
South Australia & 5 & 4 & 6 \\
Tasmania & 3 & 5 & 4 \\
Victoria & 19 & 24 & 24 \\
Western Australia & 4 & 5 & 7 \\
New Zealand & 8 & 9 & 11 \\
Total & 86 & 95 & 100 \\
\hline
\end{tabular}

quantitative urine analysis in Australasia. Summary reports of each year's results have been made available to participants and published in national professional journals. ${ }^{5-7}$

\section{Material and methods}

\section{PARTICIPANTS}

A total of 86,95 , and 100 laboratories participated in the 1981,1982 , and 1983 surveys respectively. A breakdown of participants by state and country is shown in Table 1 . Of the 100 laboratories that participated in the 1983 programme, 58 participated in the 1981 programme, 69 in the 1982 programme, and 47 in all three programmes.

\section{SURVEY SAMPLES}

Before the start of each survey participants were required to complete a questionnaire concerning the methods, instruments, standards, and quality control materials used in analysis and on the units and reference ranges used in reporting results.

During each year, at roughly two to three monthly intervals, 12 samples (in three batches of four), six samples (in three batches of two), and six samples (in three batches of two) were sent in 1981, 1982, and 1983 respectively to all participants together with a detailed instruction sheet and colour coded result sheets.

In 1981 , all survey samples were generated in the laboratory of the survey organisers from a single lot of Ortho Control Urine I (Ortho Diagnostics, Raritan, NJ 08869). An appropriate number of vials were reconstituted with a defined volume of reconstitution material to generate a series of samples with linearly related concentrations. After reconstitution, $10 \mathrm{ml}$ aliquots were dispensed into labelled plastic tubes, and these liquid samples were then distributed to participants by air cargo.

In 1982 vials of lyophilised urine quality control material, to be reconstituted by the participating laboratory, were distributed by the survey organ- isers, together with appropriate reconstitution instructions. By varying the volume of distilled water used for reconstitution, a further set of linearly related samples was generated from a second single batch of Ortho Control Urine.

In 1983 survey material was prepared, to the specifications of the survey organisers, by the Commonwealth Serum Laboratories (Parkville, Victoria 3052); such material was totally human in origin. Vials of lyophilised material, each containing $25 \mathrm{ml}$, together with appropriate reconstitution instructions were sent in kit form directly by the Commonwealth Serum Laboratories to all participants. The samples were again linearly related.

\section{RETURN OF RESULTS}

In each survey result sheets were required to be returned to the survey organisers by a previously set cut off date; data received were entered into a computer data base, which held the laboratory code number and method data of each participant. Over the three years, on average, an $80 \%$ return of results was achieved by participating laboratories.

\section{GENERATION OF INTERIM REPORTS}

About two weeks after the nominated date for return of results, individual reports, as described in detail previously, ${ }^{58}$ were sent to each laboratory.

\section{TARGET VALUES}

In 1981 and 1982 target values were, in general, assigned to the base material by replicate analysis performed at three selected reference laboratories in South Australia using a number of different methods and instrumental techniques. Since, as shown in Table 2 , the target values obtained were almost identical to the consensus mean obtained from all results excluding outliers (defined as results greater than \pm 3 SD from the overall mean), we decided to use the truncated consensus mean as the target value in 1983.

\section{ALLOWABLELIMITS OF ERROR}

Allowable limits for total laboratory error ${ }^{9}$ were set as described previously ${ }^{5-7}$ and are listed, for ease of reference, in Table 3.

\section{SUMMARY REPORT}

At the end of each survey a written report, together with a statistical summary, was sent to all participants. By using linearly related samples it was possible to analyse the results of a particular laboratory using linear regression analysis. The results from each participant were compared with the target value for each analyte and the line of best fit then determined. The lowest and highest samples distri- 
Table 2 Comparison of target and consensus values for lowest and highest samples distributed in 1981 and 1982

\begin{tabular}{|c|c|c|c|c|c|c|c|c|}
\hline \multirow[t]{3}{*}{ Analyte } & \multicolumn{4}{|c|}{ Low sample } & \multicolumn{4}{|c|}{ High sample } \\
\hline & \multicolumn{2}{|l|}{1981} & \multicolumn{2}{|l|}{1982} & \multicolumn{2}{|l|}{1981} & \multicolumn{2}{|l|}{1982} \\
\hline & Target & Consensus & Target & Consensus & Target & Consensus & Target & Consensus \\
\hline $\begin{array}{l}\text { Sodium }(\mathrm{mmol} / \mathrm{l}) \\
\text { Potassium }(\mathrm{mmol} / \mathrm{l}) \\
\text { Osmolality }(\mathrm{mmol} / \mathrm{kg}) \\
\text { Urea }(\mathrm{mmol} / \mathrm{l}) \\
\text { Creatinine }(\mathrm{mmol} / \mathrm{l}) \\
\text { Calcium }(\mathrm{mmol} / \mathrm{l}) \\
\text { Phosphate }(\mathrm{mmol} / \mathrm{l}) \\
\text { Urate }(\mathrm{mmol} / \mathrm{l}) \\
\text { Proteins }(\mathrm{g} / \mathrm{l}) \\
\text { Glucose }(\mathrm{mmol} / \mathrm{l})\end{array}$ & $\begin{array}{c}74 \\
31 \\
441 \\
206 \\
7 \cdot 4 \\
2 \cdot 65 \\
12 \cdot 0 \\
0 \cdot 58 \\
0 \cdot 36 \\
0 \cdot 5\end{array}$ & $\begin{array}{c}76 \\
32 \\
441 \\
213 \\
7 \cdot 3 \\
2 \cdot 62 \\
12 \cdot 3 \\
0.52 \\
0.36 \\
0.7\end{array}$ & $\begin{array}{l}128 \\
28 \\
494 \\
170 \\
6 \cdot 3 \\
1 \cdot 08 \\
13 \cdot 1 \\
0 \cdot 59 \\
0 \cdot 27 \\
10 \cdot 6\end{array}$ & $\begin{array}{c}129 \\
28 \\
491 \\
171 \\
6.4 \\
1 \cdot 10 \\
13.9 \\
0.56 \\
0.31 \\
9.7\end{array}$ & $\begin{array}{c}249 \\
105 \\
1482 \\
692 \\
24 \cdot 9 \\
8 \cdot 80 \\
40 \cdot 6 \\
1 \cdot 96 \\
2 \cdot 20 \\
22 \cdot 8\end{array}$ & $\begin{array}{c}248 \\
103 \\
1463 \\
702 \\
23 \cdot 6 \\
8 \cdot 74 \\
40 \cdot 0 \\
1 \cdot 74 \\
2 \cdot 17 \\
23 \cdot 2\end{array}$ & $\begin{array}{c}252 \\
54 \\
971 \\
333 \\
12 \cdot 4 \\
2 \cdot 11 \\
25 \cdot 7 \\
1 \cdot 16 \\
0 \cdot 53 \\
20 \cdot 8\end{array}$ & $\begin{array}{c}251 \\
52 \\
965 \\
329 \\
12 \cdot 0 \\
2.09 \\
25 \cdot 8 \\
1.01 \\
0.55 \\
19 \cdot 3\end{array}$ \\
\hline
\end{tabular}

Table 3 Limits for total laboratory error

\begin{tabular}{ll}
\hline Analyte & Allowable limit of error \\
\hline Sodium $(\mathrm{mmol} / \mathrm{l})$ & \pm 10 \\
Potassium $(\mathrm{mmol} / \mathrm{l})$ & \pm 5 \\
Osmolality $(\mathrm{mmol} / \mathrm{kg})$ & \pm 5 at $<300$ \\
& \pm 10 at $300-500$ \\
& \pm 20 at $>500$ \\
Urea $(\mathrm{mmol} /)$ & \pm 20 \\
Creatinine $(\mathrm{mmol} / \mathrm{l})$ & \pm 2 \\
Calcium $(\mathrm{mmol} / \mathrm{l})$ & $\pm 0 \cdot 2$ \\
Phosphate $(\mathrm{mmol} / \mathrm{l})$ & $\pm 2 \cdot 5$ \\
Urate $(\mathrm{mmol} / \mathrm{l})$ & $\pm 0 \cdot 25$ \\
Proteins $(\mathrm{g} / \mathrm{l})$ & $\pm 0 \cdot 1$ \\
Glucose $(\mathrm{mmol} / \mathrm{l})$ & \pm 1 at $\leqslant 10$ \\
Chloride $(\mathrm{mmol} / \mathrm{l})$ & \pm 2 at $>10$ \\
Oxalate $(\mathrm{mmol} / \mathrm{l})$ & \pm 10 \\
HMMA $(\mu \mathrm{mol} / \mathrm{l})$ & $\pm 0 \cdot 05$ \\
& \pm 20 at $\leqslant 100$ \\
5HIAA $(\mu \mathrm{mol} / \mathrm{l})$ & $\pm 20 \%$ at $>100$ \\
& \pm 20 at $\leqslant 100$ \\
Amylase $(\mathrm{U} / \mathrm{l})$ & $\pm 20 \%$ at $>100$ \\
\hline
\end{tabular}

buted were used as the extremes of the linear regression. Bias was calculated from the formula:

Average bias $=$ low sample bias + midpoint bias + high sample bias bias
Overall imprecision (SD) was calculated as the standard error of the estimate about the line of best fit and was considered to reflect the average laboratory SD over the range of results submitted. Imprecision and bias were also ranked from the lowest to the highest value. The median value was selected as the "average laboratory performance" for the parameter concerned.

\section{Results and discussion}

\section{CALIBRATION MATERIALS}

The range of calibration materials used by participants over the three year period is shown in Table 4 . Other materials used as calibrants that are not detailed in Table 4 include commercial cerebrospinal fluid and serum quality control material and National Bureau of Standards (Washington, DC 20234) material for the calibration of urea and calcium analyses. We believe that calibration materials should have a matrix similar to, if not identical with, the fluid being analysed, and therefore consider that the use of serum based material for the calibration of urine analyses is not satisfactory. The use of quality control materials as calibrants is totally inappropriate. The encouraging trend away from serum

Table 4 Calibration materials used in the Australasian urine programmes: 1981-1983 (percentages)

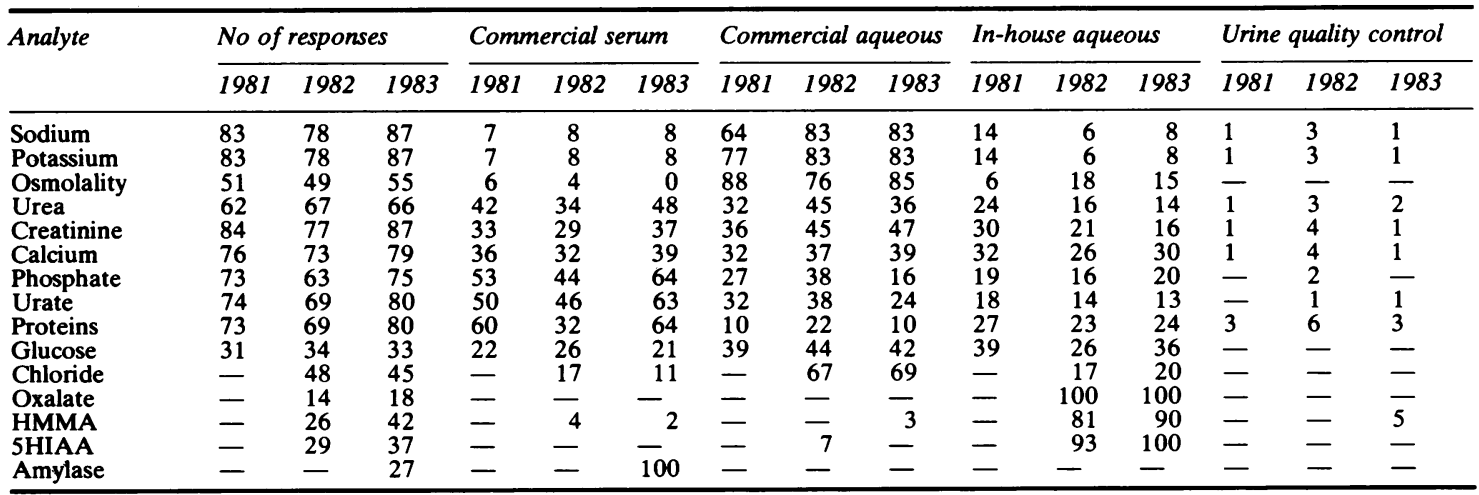


Table 5 Quality control material used in the Australasian urine programmes: 1981-1983 (percentages)

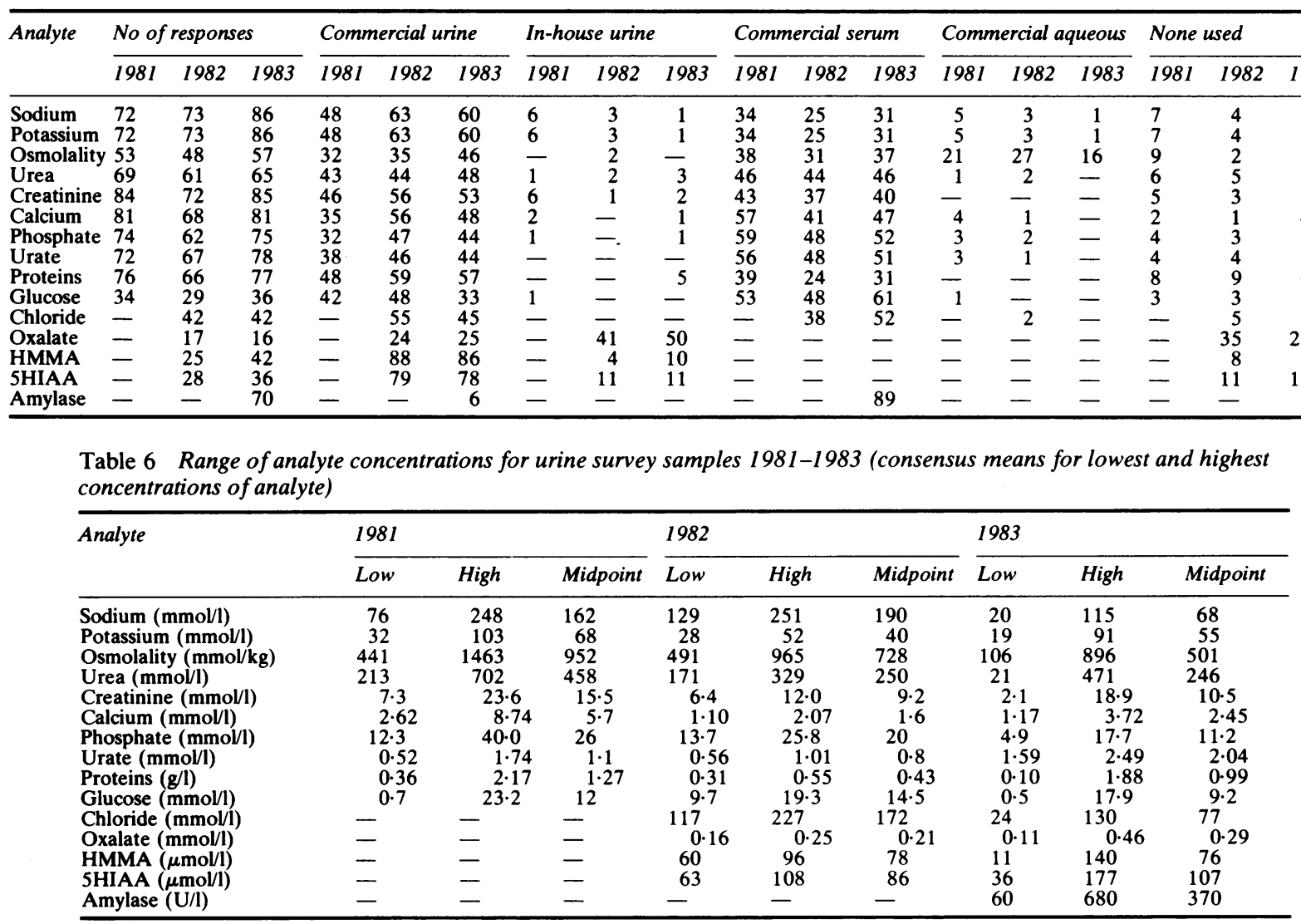

based calibrants seen in 1982 did not continue in 1983 and, for most analytes, the use of such material became even higher than in 1981 .

\section{QUALITY CONTROL MATERIALS}

The range of quality control materials used is shown in Table 5. In addition, equine serum and spinal fluid quality control materials have been used as such for the analysis of proteins; we believe that such materials should not be used. As with calibration materials, the positive trend in 1982 towards laboratories using urine materials for quality control in preference to serum materials was reversed in 1983. It is incomprehensible that a large proportion of participants consistently continues not to use any form of quality control to monitor analytical performance; this is particularly of concern for the analysis of urinary oxalate, where the standard of performance is poor.

OVERALL STANDARD OF PERFORMANCE At the end of each survey the following were calcu- lated: the number of laboratories participating; the classification of methods used and the number of laboratories using those methods; the total number of results submitted; the number and percentage of blunders (defined as those results outside the target value \pm three times the allowable limits of error); the number and percentage of unacceptable results (defined as those results outside the allowable limits of error); and the imprecision and bias, ranked at various intervals or percentiles.

Using the wealth of data available to the survey organisers, an attempt has been made to draw objective conclusions on the overall standard of performance of each analysis over the three year period. Owing to the fact that $(a)$ the survey material used was of differing origins, $(b)$ the range of analyte concentrations for the survey samples was very different from one year to the next, as shown in Table 6, and (c) the laboratories participating in each survey were not the same, this task has proved rather difficult. Throughout the evolution of the urine programme, however, identical allowable limits for total laborat- 
Table 7 Percentage of unacceptable results in the Australasian urine programmes for all participants and for the 47 laboratories that participated in all three surveys

\begin{tabular}{|c|c|c|c|c|c|c|}
\hline \multirow[t]{3}{*}{ Analyte } & \multicolumn{6}{|c|}{ Percentage of unacceptable results } \\
\hline & \multicolumn{3}{|c|}{ All laboratories } & \multicolumn{3}{|c|}{47 laboratories } \\
\hline & 1981 & 1982 & 1983 & 1981 & 1982 & 1983 \\
\hline $\begin{array}{l}\text { Sodium } \\
\text { Potassium } \\
\text { Osmolality } \\
\text { Urea } \\
\text { Creatinine } \\
\text { Calcium } \\
\text { Phosphate } \\
\text { Urate } \\
\text { Proteins } \\
\text { Glucose } \\
\text { Chloride } \\
\text { Oxalate } \\
\text { HMMA } \\
\text { 5HIAA }\end{array}$ & $\begin{array}{r}8 \\
7 \\
30 \\
45 \\
17 \\
51 \\
25 \\
38 \\
37 \\
13 \\
- \\
- \\
-\end{array}$ & $\begin{array}{r}17 \\
10 \\
30 \\
27 \\
4 \\
25 \\
26 \\
37 \\
39 \\
21 \\
14 \\
62 \\
39 \\
43\end{array}$ & $\begin{array}{r}6 \\
12 \\
25 \\
28 \\
11 \\
22 \\
15 \\
82 \\
54 \\
4 \\
5 \\
48 \\
41 \\
36\end{array}$ & $\begin{array}{r}7 \\
6 \\
28 \\
45 \\
14 \\
52 \\
19 \\
39 \\
33 \\
18 \\
- \\
- \\
-\end{array}$ & $\begin{array}{r}16 \\
10 \\
24 \\
20 \\
5 \\
23 \\
25 \\
38 \\
30 \\
17 \\
16 \\
66 \\
36 \\
50\end{array}$ & $\begin{array}{r}4 \\
9 \\
26 \\
26 \\
8 \\
22 \\
12 \\
83 \\
51 \\
2 \\
4 \\
58 \\
40 \\
28\end{array}$ \\
\hline
\end{tabular}

Table 8 Trends in analytical performance observed over a three year period

\begin{tabular}{lll}
\hline Trend & Analyte \\
\hline 1 & $\begin{array}{l}\text { Consistent improvement over } \\
\text { three years }\end{array}$ & Calcium \\
2 & $\begin{array}{l}\text { Steady progress over three } \\
\text { years }\end{array}$ & Potassium, osmolality \\
3 & $\begin{array}{l}\text { Improvement from } 1981 \text { to } \\
\text { I982, which has been maintained creatinine }\end{array}$ \\
4 & $\begin{array}{l}\text { Improvement from } 1982 \text { to } \\
\text { 1983 }\end{array}$ & $\begin{array}{l}\text { Sodium, phosphate, glucose, } \\
\text { chloride, oxalate, 5HIAA }\end{array}$ \\
5 & $\begin{array}{l}\text { Consistent decline over } \\
\text { three years }\end{array}$ & Proteins \\
\hline
\end{tabular}

ory error, as defined in Table 3 , have been used for each survey. We therefore consider that the percentage of unacceptable results represents an appropriate parameter to observe trends in overall analytical performance over the three year period. The percentages of unacceptable results submitted for all participating laboratories and for the selected group of 47 laboratories that have participated in all three urine surveys are shown in Table 7 . The trends in analytical performance observed, which are similar for all laboratories compared with the group of 47 laboratories that participated in all three surveys, are summarised in Table 8.

Table 9 summarises the conclusions concerning overall analytical performance, as at 1983 , based on the premise that the findings in 1983 reflect culmination of three years work towards improved analytical performance and the criteria that $(a)<15 \%$ of unacceptable results indicates that an analysis is performed satisfactorily, (b) 15-35\% of unacceptable results indicates that analysis requires further improvement, and $(c)$ that $>35 \%$ of unacceptable results indicates that analysis is performed poorly. As a direct consequence of the results obtained in the Australasian urine programme, working parties have been established in 1983 by the Scientific and Technical Committee of the Australian Association of Clinical Biochemists with the specific aim of improving the performance of both urinary oxalate and HMMA analyses.

The overall data obtained over three years concerning the imprecision and bias of each analyte surveyed are shown in Tables 10 and 11 . The median imprecision and bias obtained by all laboratories, the imprecision and bias obtained by the top $10 \%$ of all participating laboratories, and the median imprecision and bias obtained by the 47 laboratories participating in all three surveys is provided. The median value is considered to reflect "average" laboratory performance. As detailed earlier, since the range of analyte concentrations for the urine survey samples has been very different from one year to the next, imprecision and bias are expressed not only in absolute terms but also as coefficients of variation $(\mathrm{CV} \%)$ and coefficients of bias (CB\%) respectively, such terms being defined as:

$$
\begin{aligned}
& \mathrm{CV}=\frac{\mathrm{SD}}{\text { Midpoint of analyte concentration range }} \times 100 \% \\
& \mathrm{CB}=\frac{\mathrm{Bias}}{\text { Midpoint of analyte concentration range }} \times 100 \%
\end{aligned}
$$

Analytical goals for the imprecision of 10 of the urinary analytes surveyed have been derived by a number of approaches. ${ }^{6}$ The most stringent analytical goals obtained from such approaches are shown for each analyte in Table 12. Stevens and Cresswell $^{10}$ have previously advocated that the imprecision, expressed as one standard deviation, achieved by the top $10 \%$ of participating laboratories should be used as a target for imprecision for all laboratories. By comparing the standard of imprecision achieved by the top $10 \%$ of laboratories (Table 10) with the analytical goals, it can be seen that the analytical goals can be achieved, and in some instances have been surpassed, by this group of laboratories for urine sodium, potassium, osmolal-

Table 9 Standard of analytical performance, based on 1983 findings

\begin{tabular}{lll}
\hline Criterion & Comment & Analyte \\
\hline$<15 \%$ unacceptable results & Perform satisfactorily & Sodium, potassium, creatinine, phosphate, glucose, chloride \\
$15-35 \%$ unacceptable results & Require further improvement & Osmolality, urea, calcium \\
$>35 \%$ unacceptable results & Require substantial improvement & Proteins, oxalate, SHIAA, HMMA, urate \\
\hline
\end{tabular}


Table 10 Imprecision obtained over three years in Australasian urine programme

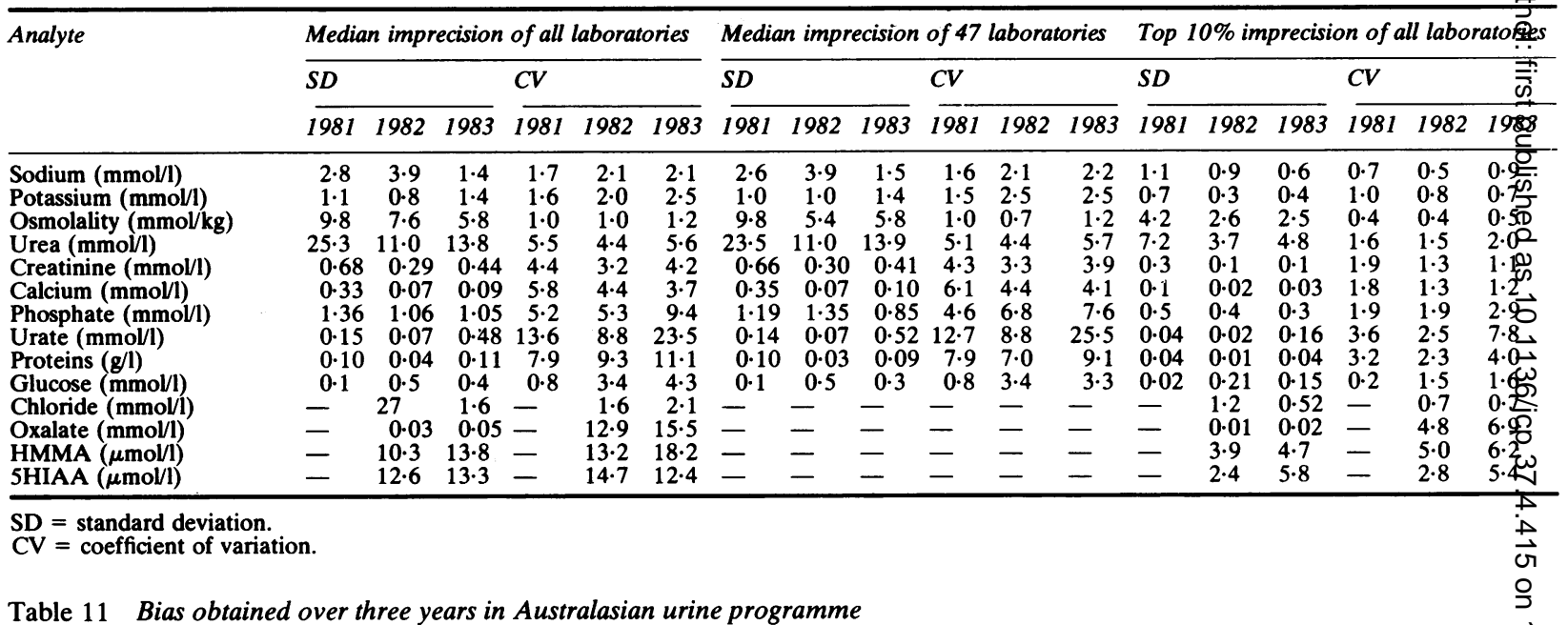

\begin{tabular}{|c|c|c|c|c|c|c|c|c|c|c|c|c|c|c|c|c|c|c|}
\hline \multirow{3}{*}{$\overline{\text { Analyte }}$} & \multicolumn{6}{|c|}{ Median bias of all laboratories } & \multicolumn{6}{|c|}{ Median bias of 47 laboratories } & \multicolumn{6}{|c|}{ Top $10 \%$ bias of all laboratories } \\
\hline & \multicolumn{3}{|l|}{ Bias } & \multicolumn{3}{|l|}{$C B$} & \multicolumn{3}{|l|}{ Bias } & \multicolumn{3}{|l|}{$C B$} & \multicolumn{3}{|l|}{ Bias } & \multicolumn{3}{|l|}{$C B$} \\
\hline & 1981 & 1982 & 1983 & $\overline{1981}$ & 1982 & 1983 & 1981 & 1982 & 1983 & 1981 & 1982 & 1983 & 1981 & 1982 & 1983 & $\overline{1981}$ & 1982 & 198 \\
\hline $\begin{array}{l}\text { Sodium }(\mathrm{mmol} / \mathrm{l}) \\
\text { Potassium }(\mathrm{mmol} / \mathrm{l}) \\
\text { Osmolality }(\mathrm{mmol} / \mathrm{kg}) \\
\text { Urea }(\mathrm{mmol} / \mathrm{l}) \\
\text { Creatinine }(\mathrm{mmol} / \mathrm{l}) \\
\text { Calcium }(\mathrm{mmol} / \mathrm{l}) \\
\text { Phosphate }(\mathrm{mmol} / \mathrm{l}) \\
\text { Urate }(\mathrm{mmol} / \mathrm{l}) \\
\text { Proteins }(\mathrm{g} / \mathrm{l}) \\
\text { Glucose }(\mathrm{mmol} / \mathrm{l}) \\
\text { Chloride }(\mathrm{mmol} / \mathrm{l}) \\
\text { Oxalate }(\mathrm{mmol} /) \\
\text { HMMA }(\mu \mathrm{mol} / \mathrm{l}) \\
\text { 5HIAA }(\mu \mathrm{mol} / \mathrm{l})\end{array}$ & $\begin{array}{c}3.8 \\
1.7 \\
15.8 \\
25.8 \\
1.19 \\
0.54 \\
1.70 \\
0.29 \\
0.22 \\
0.7 \\
- \\
- \\
-\end{array}$ & $\begin{array}{c}6 \cdot 1 \\
1.5 \\
18 \cdot 5 \\
12 \cdot 5 \\
0 \cdot 41 \\
0 \cdot 11 \\
1 \cdot 36 \\
0 \cdot 21 \\
0.08 \\
1 \cdot 3 \\
4 \cdot 8 \\
0 \cdot 05 \\
12 \cdot 1 \\
19 \cdot 0\end{array}$ & $\begin{array}{c}2.0 \\
1.5 \\
7.5 \\
11.0 \\
0.60 \\
0 \cdot 10 \\
0.95 \\
0 \cdot 48 \\
0.13 \\
0 \cdot 3 \\
2 \cdot 0 \\
0 \cdot 07 \\
20 \cdot 0 \\
16 \cdot 0\end{array}$ & $\begin{array}{r}2 \cdot 3 \\
2 \cdot 5 \\
1 \cdot 7 \\
5 \cdot 6 \\
7 \cdot 7 \\
9 \cdot 5 \\
6 \cdot 5 \\
26 \cdot 4 \\
17 \cdot 3 \\
5 \cdot 8 \\
- \\
- \\
-\end{array}$ & $\begin{array}{r}3 \cdot 2 \\
3 \cdot 8 \\
2 \cdot 5 \\
5 \cdot 0 \\
4 \cdot 5 \\
6 \cdot 9 \\
6 \cdot 8 \\
26 \cdot 3 \\
18 \cdot 6 \\
9 \cdot 0 \\
2 \cdot 8 \\
22 \cdot 4 \\
15 \cdot 5 \\
22 \cdot 1\end{array}$ & $\begin{array}{r}2 \cdot 9 \\
2 \cdot 7 \\
1 \cdot 5 \\
4 \cdot 5 \\
5 \cdot 7 \\
4 \cdot 1 \\
8 \cdot 5 \\
23 \cdot 5 \\
13 \cdot 1 \\
3 \cdot 3 \\
2 \cdot 6 \\
24 \cdot 5 \\
26 \cdot 3 \\
15 \cdot 0\end{array}$ & $\begin{array}{c}3 \cdot 7 \\
1.2 \\
17 \cdot 3 \\
25 \cdot 8 \\
1.06 \\
0 \cdot 58 \\
1.48 \\
0 \cdot 28 \\
0 \cdot 18 \\
1 \cdot 0 \\
- \\
-\end{array}$ & $\begin{array}{c}6 \cdot 0 \\
1.6 \\
15 \cdot 3 \\
10 \cdot 0 \\
0 \cdot 33 \\
0 \cdot 10 \\
1 \cdot 35 \\
0 \cdot 22 \\
0.7 \\
1 \cdot 0 \\
= \\
- \\
-\end{array}$ & $\begin{array}{c}2 \cdot 0 \\
1.3 \\
7 \cdot 3 \\
10 \cdot 1 \\
0.38 \\
0 \cdot 11 \\
0.69 \\
0.51 \\
0 \cdot 12 \\
0 \cdot 2 \\
- \\
- \\
-\end{array}$ & $\begin{array}{r}2.3 \\
1.8 \\
1.8 \\
5.6 \\
6.8 \\
10.2 \\
5.7 \\
25.5 \\
14.2 \\
8.3 \\
- \\
-\end{array}$ & $\begin{array}{c}3 \cdot 2 \\
4 \cdot 0 \\
2 \cdot 1 \\
4 \cdot 0 \\
3 \cdot 6 \\
6 \cdot 3 \\
6 \cdot 8 \\
27 \cdot 5 \\
16 \cdot 3 \\
6 \cdot 9 \\
- \\
- \\
-\end{array}$ & $\begin{array}{c}2 \cdot 9 \\
2 \cdot 4 \\
1 \cdot 5 \\
4 \cdot 1 \\
3 \cdot 6 \\
4 \cdot 5 \\
6 \cdot 2 \\
25 \cdot 0 \\
12 \cdot 1 \\
2 \cdot 2 \\
- \\
- \\
-\end{array}$ & $\begin{array}{l}1.4 \\
0.6 \\
7.7 \\
8 \cdot 3 \\
0.29 \\
0.11 \\
0.42 \\
0.06 \\
0.04 \\
0 \cdot 10 \\
- \\
- \\
-\end{array}$ & $\begin{array}{l}1.3 \\
0.6 \\
4.3 \\
4.6 \\
0.12 \\
0.03 \\
0.38 \\
0.06 \\
0.02 \\
0.21 \\
1.3 \\
0.01 \\
4.0 \\
3.3\end{array}$ & $\begin{array}{l}0.6 \\
0.2 \\
2.4 \\
4.4 \\
0.09 \\
0.03 \\
0.28 \\
0.21 \\
0.05 \\
0.11 \\
0.6 \\
0.02 \\
4.7 \\
6.4\end{array}$ & $\begin{array}{l}0.9 \\
0.9 \\
0.8 \\
1.8 \\
1.9 \\
1.9 \\
1.6 \\
5.5 \\
3.1 \\
0.8 \\
- \\
- \\
-\end{array}$ & $\begin{array}{l}0.7 \\
1.4 \\
0.6 \\
1.8 \\
1.3 \\
1.8 \\
1.9 \\
7.5 \\
4.7 \\
1.4 \\
0.8 \\
3.8 \\
5.1 \\
3.8\end{array}$ & $\begin{array}{r}0 \\
10 \\
0.8 \\
18 \\
2.8 \\
10.3 \\
5.8 \\
10 \\
0.7 \\
6.7 \\
6.0 \\
6.0\end{array}$ \\
\hline
\end{tabular}

Table 12 Analytical goals for the imprecision of quantitative urine analyses

\begin{tabular}{ll}
\hline Analyte & Analytical goal \\
\hline Sodium (mmol/l) & $0 \cdot 7$ \\
Potassium (mmol/l) & 0.5 \\
Osmolality (mmol/kg) & 2.5 \\
Urea (mmol/l) & 3.6 \\
Creatinine (mmol/l) & $0 \cdot 4$ \\
Calcium $(\mathrm{mmol} / \mathrm{l})$ & $0 \cdot 1$ \\
Phosphate $(\mathrm{mmol} / \mathrm{l})$ & 0.7 \\
Urate $(\mathrm{mmol} / \mathrm{l})$ & $0 \cdot 1$ \\
Proteins $(\mathrm{g} / \mathrm{l})$ & 0.01 \\
Glucose $(\mathrm{mmol} / \mathrm{l})$ & 0.06 \\
\hline
\end{tabular}

ity, creatinine, calcium, and phosphate. Furthermore, imprecision, in SD terms, has continued to improve for urine sodium, osmolality, and phosphate.

Over the three year period more than $5 \%$ of results submitted were classed as blunders, in at least two of the three years, for the analyses of osmolality, urea, calcium, urate, proteins, oxalate, and 5HIAA. As well as being due to inherently poor analytical technique, blunders were mainly attributed to transcription, dilution, or calculation mistakes. For osmolality we recommend that attention should also be paid to calibration with a material which has an analyte concentration similar to that of routine urine specimens. For urate it was evident that some laboratories were not aware that urate precipitates in an acidic urine and, as a result, did not take the preanalytical precaution of alkalinising urine specimens submitted for urate analysis. ${ }^{11}$

\section{COMPARISON OF INDIVIDUAL METHODS FOR}

EACH ANALYTE

A critical assessment of the suitability of individual methods for routine laboratory use has been attempted using the data summarised in Table 13. 
Table 13 Comparative performance of individual methods

\begin{tabular}{|c|c|c|c|c|c|c|c|c|c|c|c|c|c|c|c|c|}
\hline \multirow[t]{2}{*}{ Analyte } & \multirow[t]{2}{*}{ Method } & \multicolumn{3}{|c|}{$\begin{array}{l}\text { No of } \\
\text { laboratories }\end{array}$} & \multicolumn{3}{|c|}{$\begin{array}{l}\text { Results } \\
\text { submitted }\end{array}$} & \multicolumn{3}{|c|}{$\begin{array}{l}\text { Percentage } \\
\text { unacceptable }\end{array}$} & \multicolumn{3}{|c|}{$\begin{array}{l}\text { Imprecision } \\
\text { (median SD of } \\
\text { all laboratories) }\end{array}$} & \multicolumn{3}{|c|}{$\begin{array}{l}\text { Bias } \\
\text { (median bias of } \\
\text { all laboratories) }\end{array}$} \\
\hline & & 1981 & 1982 & 1983 & 1981 & 1982 & 1983 & 1981 & 1982 & 1983 & 1981 & 1982 & 1983 & 1981 & 1982 & 1983 \\
\hline Sodium & $\begin{array}{l}\text { All } \\
\text { Flame photometry-direct } \\
\text { Flame-continuous flow } \\
\text { lon selective electrode }\end{array}$ & $\begin{array}{r}82 \\
59 \\
9 \\
7\end{array}$ & $\begin{array}{r}91 \\
61 \\
8 \\
16\end{array}$ & $\begin{array}{r}94 \\
41 \\
9 \\
32\end{array}$ & $\begin{array}{r}916 \\
656 \\
96 \\
80\end{array}$ & $\begin{array}{r}485 \\
320 \\
47 \\
85\end{array}$ & $\begin{array}{r}510 \\
214 \\
50 \\
180\end{array}$ & $\begin{array}{l}8 \\
9 \\
9 \\
1\end{array}$ & $\begin{array}{l}17 \\
18 \\
15 \\
14\end{array}$ & $\begin{array}{r}6 \\
4 \\
12 \\
6\end{array}$ & $\begin{array}{l}2 \cdot 8 \\
3 \cdot 0 \\
3 \cdot 2 \\
2 \cdot 3\end{array}$ & $\begin{array}{l}3 \cdot 9 \\
3 \cdot 9 \\
3 \cdot 6 \\
1 \cdot 2\end{array}$ & $\begin{array}{l}1 \cdot 4 \\
1 \cdot 0 \\
1 \cdot 5 \\
1 \cdot 6\end{array}$ & $\begin{array}{l}3 \cdot 8 \\
4 \cdot 2 \\
3 \cdot 7 \\
1 \cdot 5\end{array}$ & $\begin{array}{l}6 \cdot 1 \\
6 \cdot 1 \\
6 \cdot 2 \\
3 \cdot 4\end{array}$ & $\begin{array}{l}2 \cdot 0 \\
2 \cdot 0 \\
1 \cdot 3 \\
1 \cdot 9\end{array}$ \\
\hline Potassium & $\begin{array}{l}\text { All } \\
\text { Flame photometry-direct } \\
\text { Flame-continuous flow } \\
\text { Ion selective electrode }\end{array}$ & $\begin{array}{r}82 \\
59 \\
9 \\
7\end{array}$ & $\begin{array}{r}91 \\
62 \\
8 \\
16\end{array}$ & $\begin{array}{r}94 \\
41 \\
9 \\
32\end{array}$ & $\begin{array}{r}918 \\
656 \\
98 \\
80\end{array}$ & $\begin{array}{r}486 \\
325 \\
47 \\
85\end{array}$ & $\begin{array}{r}508 \\
214 \\
50 \\
178\end{array}$ & $\begin{array}{r}7 \\
6 \\
21 \\
3\end{array}$ & $\begin{array}{r}10 \\
9 \\
15 \\
13\end{array}$ & $\begin{array}{r}12 \\
9 \\
6 \\
15\end{array}$ & $\begin{array}{l}1 \cdot 1 \\
1 \cdot 3 \\
3 \cdot 9 \\
0 \cdot 9\end{array}$ & $\begin{array}{l}0 \cdot 8 \\
0 \cdot 8 \\
1 \cdot 0 \\
0 \cdot 8\end{array}$ & $\begin{array}{l}1.4 \\
1 \cdot 2 \\
1.4 \\
1 \cdot 6\end{array}$ & $\begin{array}{l}1 \cdot 7 \\
1 \cdot 1 \\
3 \cdot 3 \\
1 \cdot 5\end{array}$ & $\begin{array}{l}1 \cdot 5 \\
1 \cdot 3 \\
1 \cdot 3 \\
2 \cdot 1\end{array}$ & $\begin{array}{l}1 \cdot 5 \\
1 \cdot 4 \\
1 \cdot 8 \\
1 \cdot 4\end{array}$ \\
\hline Osmolality & $\begin{array}{l}\text { All } \\
\text { Freezing point depression }\end{array}$ & 58 & 60 & 64 & 622 & 311 & 347 & 30 & 30 & 25 & $9 \cdot 8$ & $7 \cdot 6$ & $5 \cdot 8$ & $15 \cdot 8$ & 18.7 & $7 \cdot 5$ \\
\hline & $\begin{array}{l}\text { Knauer } \\
\text { Fiske } \\
\text { Advanced } \\
\text { Osmette } \\
\text { Vapour pressure }\end{array}$ & $\begin{array}{r}9 \\
11 \\
24 \\
5 \\
6\end{array}$ & $\begin{array}{r}9 \\
12 \\
20 \\
8 \\
8\end{array}$ & $\begin{array}{r}5 \\
11 \\
27 \\
9 \\
5\end{array}$ & $\begin{array}{r}100 \\
112 \\
263 \\
52 \\
64\end{array}$ & $\begin{array}{r}43 \\
56 \\
117 \\
47 \\
35\end{array}$ & $\begin{array}{r}26 \\
59 \\
146 \\
52 \\
30\end{array}$ & $\begin{array}{l}39 \\
32 \\
23 \\
14 \\
28\end{array}$ & $\begin{array}{l}49 \\
34 \\
15 \\
26 \\
63\end{array}$ & $\begin{array}{l}38 \\
31 \\
15 \\
13 \\
63\end{array}$ & $\begin{array}{r}15 \cdot 9 \\
13 \cdot 5 \\
8 \cdot 1 \\
4 \cdot 6 \\
10 \cdot 6\end{array}$ & $\begin{array}{r}9 \cdot 0 \\
9 \cdot 3 \\
4 \cdot 2 \\
7 \cdot 1 \\
10 \cdot 0\end{array}$ & $\begin{array}{l}- \\
5 \cdot 8 \\
5 \cdot 0 \\
4 \cdot 3 \\
9 \cdot 6\end{array}$ & $\begin{array}{l}15 \cdot 7 \\
23 \cdot 1 \\
13 \cdot 4 \\
14 \cdot 1 \\
14 \cdot 4\end{array}$ & $\begin{array}{l}19 \cdot 0 \\
24 \cdot 7 \\
10 \cdot 1 \\
18 \cdot 6 \\
27 \cdot 3\end{array}$ & $\begin{array}{r}\overline{7} \cdot 1 \\
6 \cdot 6 \\
6 \cdot 2 \\
12 \cdot 2\end{array}$ \\
\hline Urea & $\begin{array}{l}\text { All } \\
\text { Diacetyl monoxime } \\
\text { Urease } \\
\text { Urease/conductivity }\end{array}$ & $\begin{array}{r}70 \\
36 \\
20 \\
3\end{array}$ & $\begin{array}{r}74 \\
32 \\
27 \\
5\end{array}$ & $\begin{array}{r}76 \\
31 \\
24 \\
9\end{array}$ & $\begin{array}{r}741 \\
382 \\
227 \\
32\end{array}$ & $\begin{array}{r}384 \\
170 \\
140 \\
30\end{array}$ & $\begin{array}{r}391 \\
166 \\
121 \\
52\end{array}$ & $\begin{array}{l}45 \\
45 \\
50 \\
28\end{array}$ & $\begin{array}{l}27 \\
21 \\
32 \\
33\end{array}$ & $\begin{array}{l}28 \\
26 \\
33 \\
19\end{array}$ & $\begin{array}{l}25 \cdot 3 \\
25 \cdot 5 \\
28 \cdot 6 \\
-\end{array}$ & $\begin{array}{l}11 \cdot 0 \\
10 \cdot 7 \\
15 \cdot 3 \\
26 \cdot 5\end{array}$ & $\begin{array}{l}13 \cdot 8 \\
11 \cdot 8 \\
22 \cdot 0 \\
10 \cdot 2\end{array}$ & $\begin{array}{l}25 \cdot 8 \\
23 \cdot 3 \\
32 \cdot 3 \\
-\end{array}$ & $\begin{array}{l}12 \cdot 5 \\
10 \cdot 0 \\
12 \cdot 2 \\
12 \cdot 2\end{array}$ & $\begin{array}{r}11 \cdot 0 \\
9 \cdot 2 \\
21 \cdot 9 \\
9 \cdot 8\end{array}$ \\
\hline Creatinine & $\begin{array}{l}\text { All } \\
\text { Jaffe-kinetic } \\
\text { Jaffe-end point }\end{array}$ & $\begin{array}{l}83 \\
39 \\
38\end{array}$ & $\begin{array}{l}90 \\
45 \\
33\end{array}$ & $\begin{array}{l}96 \\
46 \\
33\end{array}$ & $\begin{array}{l}922 \\
436 \\
422\end{array}$ & $\begin{array}{l}478 \\
236 \\
177\end{array}$ & $\begin{array}{l}514 \\
251 \\
177\end{array}$ & $\begin{array}{l}17 \\
17 \\
16\end{array}$ & $\begin{array}{l}4 \\
6 \\
3\end{array}$ & $\begin{array}{r}11 \\
14 \\
6\end{array}$ & $\begin{array}{l}0.68 \\
0.61 \\
0.71\end{array}$ & $\begin{array}{l}0.29 \\
0 \cdot 29 \\
0.32\end{array}$ & $\begin{array}{l}0.44 \\
0.42 \\
0.42\end{array}$ & $\begin{array}{l}1.19 \\
1.25 \\
1.13\end{array}$ & $\begin{array}{l}0.41 \\
0.50 \\
0.37\end{array}$ & $\begin{array}{l}0.60 \\
0 \cdot 61 \\
0.50\end{array}$ \\
\hline Calcium & $\begin{array}{l}\text { All } \\
\text { Cresolphthalein complexone } \\
\text { Methyl thymol blue } \\
\text { Atomic absorption } \\
\text { Corning titrator } \\
\text { Calcette titrator }\end{array}$ & $\begin{array}{r}79 \\
30 \\
4 \\
27 \\
11 \\
2\end{array}$ & $\begin{array}{r}81 \\
33 \\
8 \\
26 \\
8 \\
4\end{array}$ & $\begin{array}{r}91 \\
34 \\
9 \\
23 \\
12 \\
3\end{array}$ & $\begin{array}{r}858 \\
325 \\
44 \\
287 \\
112 \\
20\end{array}$ & $\begin{array}{r}427 \\
176 \\
42 \\
132 \\
41 \\
22\end{array}$ & $\begin{array}{r}488 \\
182 \\
53 \\
124 \\
65 \\
14\end{array}$ & $\begin{array}{l}51 \\
60 \\
71 \\
50 \\
25 \\
35\end{array}$ & $\begin{array}{l}25 \\
37 \\
19 \\
18 \\
12 \\
14\end{array}$ & $\begin{array}{r}22 \\
29 \\
17 \\
21 \\
14 \\
0\end{array}$ & $\begin{array}{l}0.33 \\
0.39 \\
-\quad \\
0 \cdot 30 \\
0 \cdot 13 \\
-\end{array}$ & $\begin{array}{l}0.07 \\
0.09 \\
0 \cdot 05 \\
0.05 \\
0.04 \\
-\end{array}$ & $\begin{array}{l}0.09 \\
0.16 \\
0 \cdot 10 \\
0.08 \\
0.04 \\
-\quad\end{array}$ & $\begin{array}{l}0.54 \\
0.62 \\
-\quad \\
0.80 \\
0.38 \\
-\end{array}$ & $\begin{array}{l}0.11 \\
0.18 \\
0 \cdot 12 \\
0 \cdot 10 \\
0.03\end{array}$ & $\begin{array}{l}0.10 \\
0.14 \\
0.07 \\
0.11 \\
0.09 \\
-\end{array}$ \\
\hline Phosphate & $\begin{array}{l}\text { All } \\
\text { Phosphomolybdovanadate } \\
\text { Phosphomolybdate reduction }\end{array}$ & $\begin{array}{r}75 \\
8 \\
60\end{array}$ & $\begin{array}{r}75 \\
5 \\
64\end{array}$ & $\begin{array}{r}82 \\
5 \\
67\end{array}$ & $\begin{array}{r}771 \\
96 \\
603\end{array}$ & $\begin{array}{r}394 \\
24 \\
341\end{array}$ & $\begin{array}{r}433 \\
26 \\
357\end{array}$ & $\begin{array}{l}25 \\
12 \\
25\end{array}$ & $\begin{array}{l}26 \\
38 \\
26\end{array}$ & $\begin{array}{l}15 \\
12 \\
15\end{array}$ & $\begin{array}{l}1 \cdot 36 \\
0 \cdot 96 \\
1 \cdot 34\end{array}$ & $\frac{1.06}{0.96}$ & $-_{1.05}^{1.05}$ & $\begin{array}{l}1.70 \\
1.02 \\
1.73\end{array}$ & $\frac{1 \cdot 36}{1 \cdot 31}$ & $\begin{array}{c}0.95 \\
-0.83\end{array}$ \\
\hline Urate & $\begin{array}{l}\text { All } \\
\text { Phosphotungstate reduction } \\
\text { Uricase } \\
\text { Metal complex reduction }\end{array}$ & $\begin{array}{r}77 \\
31 \\
38 \\
1\end{array}$ & $\begin{array}{r}82 \\
28 \\
46 \\
1\end{array}$ & $\begin{array}{l}86 \\
26 \\
49 \\
-\end{array}$ & $\begin{array}{r}890 \\
392 \\
418 \\
4\end{array}$ & $\begin{array}{r}421 \\
149 \\
236 \\
6\end{array}$ & $\begin{array}{l}436 \\
136 \\
249 \\
-\end{array}$ & $\begin{array}{l}38 \\
24 \\
52 \\
75\end{array}$ & $\begin{array}{l}37 \\
23 \\
45 \\
83\end{array}$ & $\begin{array}{l}82 \\
82 \\
82 \\
-\end{array}$ & $\begin{array}{l}0.15 \\
0.17 \\
0.14 \\
-\end{array}$ & $\begin{array}{l}0.07 \\
0.09 \\
0.05 \\
-\end{array}$ & $\begin{array}{l}0.48 \\
0.39 \\
0.54 \\
-\end{array}$ & $\begin{array}{l}0.29 \\
0.15 \\
0.39 \\
-\end{array}$ & $\begin{array}{l}0.21 \\
0.12 \\
0.25 \\
-\end{array}$ & $\begin{array}{l}0.48 \\
0.50 \\
0.46 \\
-\end{array}$ \\
\hline Proteins & $\begin{array}{l}\text { All } \\
\text { TCA/ponceau S } \\
\text { TCA/biuret } \\
\text { SSA/biuret } \\
\text { SSA turbidimetry } \\
\text { TCA turbidimetry } \\
\text { Coomassie blue }\end{array}$ & $\begin{array}{r}80 \\
17 \\
5 \\
4 \\
22 \\
20 \\
5\end{array}$ & $\begin{array}{r}96 \\
15 \\
4 \\
4 \\
25 \\
19 \\
6\end{array}$ & $\begin{array}{r}93 \\
18 \\
7 \\
1 \\
17 \\
16 \\
12\end{array}$ & $\begin{array}{r}848 \\
186 \\
56 \\
46 \\
213 \\
211 \\
60\end{array}$ & $\begin{array}{r}452 \\
86 \\
22 \\
23 \\
126 \\
103 \\
30\end{array}$ & $\begin{array}{r}488 \\
95 \\
40 \\
6 \\
79 \\
91 \\
61\end{array}$ & $\begin{array}{l}37 \\
25 \\
39 \\
44 \\
41 \\
39 \\
25\end{array}$ & $\begin{array}{l}39 \\
19 \\
27 \\
26 \\
78 \\
24 \\
20\end{array}$ & $\begin{array}{l}54 \\
43 \\
70 \\
50 \\
75 \\
57 \\
49\end{array}$ & $\begin{array}{l}0 \cdot 10 \\
0 \cdot 14 \\
0 \cdot 05 \\
0 \cdot 06 \\
0 \cdot 12 \\
0 \cdot 10 \\
0 \cdot 15\end{array}$ & $\begin{array}{l}0 \cdot 04 \\
0 \cdot 03 \\
- \\
- \\
0 \cdot 04 \\
0 \cdot 04 \\
0 \cdot 01\end{array}$ & $\begin{array}{l}0.11 \\
0 \cdot 08 \\
0 \cdot 12 \\
-\quad 0.14 \\
0 \cdot 10 \\
0 \cdot 18\end{array}$ & $\begin{array}{l}0.22 \\
0.21 \\
0.11 \\
0.22 \\
0.46 \\
0.32 \\
0.10\end{array}$ & $\begin{array}{l}0.08 \\
0.06 \\
- \\
- \\
0.23 \\
0.07 \\
0.06\end{array}$ & $\begin{array}{l}0.13 \\
0.09 \\
0 \cdot 19 \\
-\quad \\
0.31 \\
0.13 \\
0.14\end{array}$ \\
\hline Glucose & $\begin{array}{l}\text { All } \\
\text { Glucose oxidase } \\
\text { Hexokinase } \\
\mathrm{O}_{2} \text { rate-Beckman } \\
\mathrm{O}_{2} \text { rate-Yellow Springs }\end{array}$ & $\begin{array}{r}44 \\
9 \\
6 \\
7 \\
5\end{array}$ & $\begin{array}{r}44 \\
13 \\
10 \\
11 \\
2\end{array}$ & $\begin{array}{r}45 \\
7 \\
10 \\
12 \\
2\end{array}$ & $\begin{array}{r}355 \\
65 \\
65 \\
67 \\
51\end{array}$ & $\begin{array}{r}229 \\
72 \\
51 \\
66 \\
12\end{array}$ & $\begin{array}{r}229 \\
42 \\
50 \\
67 \\
10\end{array}$ & $\begin{array}{r}13 \\
2 \\
2 \\
2 \\
37\end{array}$ & $\begin{array}{r}21 \\
13 \\
29 \\
21 \\
8\end{array}$ & $\begin{array}{l}4 \\
5 \\
2 \\
1 \\
0\end{array}$ & $\begin{array}{l}0 \cdot 1 \\
0 \cdot 1 \\
0 \cdot 1 \\
0 \cdot 1 \\
0 \cdot 5\end{array}$ & $\begin{array}{l}0.5 \\
0.4 \\
0.7 \\
0.5 \\
-\end{array}$ & $\begin{array}{l}0.4 \\
0.3 \\
0.2 \\
0.4 \\
-\end{array}$ & $\begin{array}{l}0.7 \\
0.7 \\
0.3 \\
0.3 \\
0.6\end{array}$ & $\begin{array}{l}1.3 \\
1.2 \\
0.9 \\
1.4 \\
-\end{array}$ & $\begin{array}{l}0 \cdot 3 \\
0 \cdot 3 \\
0 \cdot 3 \\
0 \cdot 3 \\
-\end{array}$ \\
\hline Chloride & $\begin{array}{l}\text { All } \\
\text { Silver titration } \\
\text { Mercury titration } \\
\text { Thiocyanate/nitrate }\end{array}$ & $\begin{array}{l}z \\
-\end{array}$ & $\begin{array}{r}57 \\
35 \\
9 \\
8\end{array}$ & $\begin{array}{r}57 \\
29 \\
-9\end{array}$ & $\begin{array}{l}- \\
-\end{array}$ & $\begin{array}{r}228 \\
172 \\
41 \\
42\end{array}$ & $\begin{array}{r}273 \\
153 \\
-42\end{array}$ & $\begin{array}{l}z \\
z\end{array}$ & $\begin{array}{r}14 \\
6 \\
22 \\
36\end{array}$ & $\begin{array}{r}5 \\
3 \\
10\end{array}$ & $\begin{array}{l}- \\
-\end{array}$ & $\begin{array}{l}2 \cdot 7 \\
2 \cdot 2 \\
2 \cdot 7 \\
4 \cdot 2\end{array}$ & $\begin{array}{r}1 \cdot 6 \\
1 \cdot 4 \\
-2 \cdot 2\end{array}$ & $\begin{array}{l}- \\
z\end{array}$ & $\begin{array}{l}4 \cdot 8 \\
3 \cdot 4 \\
8 \cdot 1 \\
8 \cdot 3\end{array}$ & $\begin{array}{r}2.0 \\
1.8 \\
-1.4\end{array}$ \\
\hline Oxalate & All & - & 12 & 17 & - & 52 & 80 & - & 62 & 48 & - & 0.03 & 0.05 & 5 & 0.05 & 0.07 \\
\hline HMMA & $\begin{array}{l}\text { All } \\
\text { Oxidation to vanillin } \\
p \text {-nitroaniline }\end{array}$ & E & $\begin{array}{r}32 \\
18 \\
4\end{array}$ & $\begin{array}{r}40 \\
19 \\
7\end{array}$ & E & $\begin{array}{r}142 \\
80 \\
20\end{array}$ & $\begin{array}{r}204 \\
105 \\
36\end{array}$ & 二 & $\begin{array}{l}39 \\
36 \\
25\end{array}$ & $\begin{array}{l}41 \\
30 \\
50\end{array}$ & Z & $\begin{array}{l}10 \cdot 3 \\
11 \cdot 9 \\
-\end{array}$ & $\begin{array}{r}13 \cdot 8 \\
12 \cdot 8 \\
8 \cdot 2\end{array}$ & $\overline{-}$ & $\begin{array}{l}12 \cdot 1 \\
19 \cdot 4 \\
-\end{array}$ & $\begin{array}{l}20 \cdot 0 \\
16 \cdot 2 \\
24 \cdot 1\end{array}$ \\
\hline 5HIAA & $\begin{array}{l}\text { All } \\
\text { Nitrosonaphthol }\end{array}$ & - & $\begin{array}{l}30 \\
22\end{array}$ & $\begin{array}{l}34 \\
23\end{array}$ & - & $\begin{array}{l}150 \\
115\end{array}$ & $\begin{array}{l}168 \\
116\end{array}$ & - & $\begin{array}{l}43 \\
44\end{array}$ & $\begin{array}{l}36 \\
38\end{array}$ & - & $\begin{array}{l}12 \cdot 6 \\
12 \cdot 4\end{array}$ & $\begin{array}{l}13 \cdot 3 \\
12 \cdot 3\end{array}$ & 二 & $\begin{array}{l}19 \cdot 0 \\
20 \cdot 3\end{array}$ & $\begin{array}{l}16 \cdot 0 \\
17 \cdot 0\end{array}$ \\
\hline
\end{tabular}

The number of laboratories and results submitted do not add up to the respective totals, owing to the fact that "miscellaneous" methods for each analyte are not included in the table.

TCA = trichloroacetic acid.

SSA = sulphosalicyclic acid 
Table 14 Methods with poor and better performance, assessed by the percentage of unacceptable results

\begin{tabular}{|c|c|}
\hline Analyte & Method \\
\hline \multicolumn{2}{|c|}{ Methods with poor performance } \\
\hline Osmolality & $\begin{array}{l}\text { Freezing point depression-Knauer } \\
\text { Vapour pressure-Westcor }\end{array}$ \\
\hline Calcium & Cresophthalein complexone \\
\hline Urate & Uricase \\
\hline Proteins & $\begin{array}{l}\text { TCA-biuret } \\
\text { SSA-biuret }\end{array}$ \\
\hline Oxalate & $\begin{array}{l}\text { TCA-turbidimetry } \\
\text { All methods }\end{array}$ \\
\hline SHIAA & Nitrosonaphthol \\
\hline \multicolumn{2}{|c|}{ Methods with good performance } \\
\hline Sodium & $\begin{array}{l}\text { Flame photometry-direct } \\
\text { Ion selective electrode }\end{array}$ \\
\hline $\begin{array}{l}\text { Potassium } \\
\text { Creatinine }\end{array}$ & $\begin{array}{l}\text { Flame photometry-direct } \\
\text { Jaffe-end point }\end{array}$ \\
\hline Glucose & $\begin{array}{l}\text { Glucose oxidase } \\
\text { Hexokinase } \\
\text { O rate-Beckman }\end{array}$ \\
\hline Chloride & Silver titration \\
\hline
\end{tabular}

For abbreviations see Table 13.

Table 15 Methods with poor and good performance characteristics, assessed by median imprecision and bias

\begin{tabular}{|c|c|}
\hline Analyte & Method \\
\hline $\begin{array}{l}\text { Poor imprecision and poc } \\
\text { Osmolality } \\
\text { Urea } \\
\text { Calcium }\end{array}$ & $\begin{array}{l}\text { bias } \\
\text { Vapour pressure-Westcor } \\
\text { Urease } \\
\text { Cresolphthalein complexone }\end{array}$ \\
\hline $\begin{array}{l}\text { Good imprecision and go } \\
\text { Calcium } \\
\text { Proteins }\end{array}$ & $\begin{array}{l}\text { od bias } \\
\text { Corning titrator } \\
\text { TCA/Ponceau S }\end{array}$ \\
\hline $\begin{array}{l}\text { Poor imprecision (only) } \\
\text { Chloride }\end{array}$ & Thiocyanate/nitrate \\
\hline $\begin{array}{l}\text { Poor bias (only) } \\
\text { Osmolality } \\
\text { Proteins }\end{array}$ & $\begin{array}{l}\text { Fiske osmometer } \\
\text { SSA turbidimetry }\end{array}$ \\
\hline $\begin{array}{l}\text { Good imprecision (only) } \\
\text { Osmolality }\end{array}$ & Osmette osmometer \\
\hline $\begin{array}{l}\text { Good bias (only) } \\
\text { Sodium } \\
\text { Urate } \\
\text { Glucose }\end{array}$ & $\begin{array}{l}\text { Ion selective electrode } \\
\text { Phosphotungstate reduction } \\
\text { Hexokinase }\end{array}$ \\
\hline $\begin{array}{l}\text { Poor imprecision but goo } \\
\text { Proteins }\end{array}$ & $\begin{array}{l}\mathrm{d} \text { bias } \\
\text { Coomassie blue }\end{array}$ \\
\hline
\end{tabular}

For abbreviations see Table 13.

Two methods-namely, metal complex reduction for the analysis of urinary urate and sulphosalicyclic acid turbidimetry for urine protein assay-are considered to be unsuitable for routine urine analyses. These two methods have, for two years in succession, had more than $70 \%$ of results submitted outside the allowable limits of error. Metal complex reduction was accordingly discontinued in the 1983 urine survey. In 1982 the high level of unacceptable results for the sulphosalicyclic acid turbidimetric method was considered to reflect the fact that the survey material, in that year, contained a small amount of bovine albumin. The continued high level of unacceptable results recorded by this method in 1983 using a totally human based matrix, however, raises serious doubts as to the validity of this method for routine analytical purposes.

Methods assessed as having shown poor performance and good performance, using the criterion that the percentage of unacceptable results, for at least two out of three years, was $>35 \%$ or $<10 \%$ respectively, are shown in Table 14.

Table 13 also shows the median imprecision and bias for individual methods. Such data were calculated for those method groups in which 36 or more results were submitted in a particular year. The median value was chosen, again, since it was considered to reflect the "average" performance of an individual method group. For the reasons outlined earlier in this paper, it is difficult to draw conclusions on the comparative performance of methods in terms of trends over a three year period. By comparing the differences in magnitude of the imprecision and bias, expressed in absolute terms, between individual methods within a given year, however, objective conclusions are possible.

Methods considered to show poor and good performance characteristics, in terms of imprecision and bias, are listed in Table 15 . The criterion used for classifying methods into these categories was that if the median imprecision or bias or both of a particular method was $25 \%$ better (or worse) than the "all method" median imprecision or bias or both for a particular analyte for at least two out of the three years, then that particular method was deemed to display good (or poor) imprecision or bias or both respectively.

Throughout the Australasian urine quality assurance programme individual participants have been urged to examine critically the summary of their performance and assess the imprecision, inaccuracy, and linearity of their methods. At the end of the third year the survey organisers believed that the wealth of data generated from these surveys should be summarised in a manner which all laboratories could use positively to achieve a generally higher standard of performance in the future. We hope that this report facilitates this aim.

\section{References}

' Glenn GC, Hathaway, TK. Urine chemistry: a new CAP program. Am J Clin Pathol 1977;68:153-8.

${ }^{2}$ Glenn GC. The CAP urine chemistry survey program for 1977. Am J Clin Pathol 1978;70:513-5. 
${ }^{3}$ Glenn GC. Evolution of the urine chemistry survey program of the CAP. Am J Clin Pathol 1979;72:299-305.

4 Shephard MDS, Penberthy LA, Fraser CG. Analytical goals for quantitative urine analysis. Pathology 1981;13:543-6.

s Shephard MDS, Penberthy LA, Fraser CG. A quality assurance programme for quantitative urine analyses. Pathology 1982;14:327-31.

- Shephard MDS, Penberthy LA, Fraser CG. The 1982 Australasian programme for quantitative urine analysis. Clin Biochem Revs 1983;3:128-32.

'Shephard MDS, Penberthy LA, Fraser CG. The 1983 Australasian programme for quantitative urine analysis. Clin Biochem Revs (in press).

- Bowyer RC, Geary TD, Penberthy LA, Thomas DW. An Australian quality control scheme for clinical chemistry. The Clinical Biochemist Newsletter 1981;60:43-9.
${ }^{9}$ Westgard JO. Precision and accuracy: concepts and assessment by method evaluation testing. CRC Crit Revs Clin Lab Sci 1981:13:283-330.

${ }^{10}$ Stevens JF, Cresswell MA. Achievable standards of laboratory performance. News Sheet. Association of Clinical Biochemists Ltd 1978;182:12-3.

"Shephard MDS, Mazzachi RD. The collection, preservation, storage and stability of urine specimens for routine clinical biochemical analysis. Clin Biochem Revs 1983;4:61-7.

Requests for reprints to: Mr MDS Shephard, Department of Clinical Biochemistry, Flinders Medical Centre, Bedford Park, South Australia 5042, Australia. 